\title{
Assessing the protective effect of mountain forests against rockfall using a 3D simulation model
}

\author{
Markus Stoffel ${ }^{\mathrm{a}, *}$, André Wehrli ${ }^{\mathrm{b}}$, Roderick Kühne ${ }^{\mathrm{c}}$, Luuk K.A. Dorren ${ }^{\mathrm{d}}$, \\ Simone Perret ${ }^{c}$, Hans Kienholz ${ }^{c}$ \\ ${ }^{a}$ Department of Geosciences, Geography, University of Fribourg, Pérolles, Chemin du Musée 4, CH-1700 Fribourg, Switzerland \\ ${ }^{\mathrm{b}}$ Swiss Federal Institute for Forest, Snow and Landscape Research WSL, Zürcherstrasse 111, CH-8903 Birmensdorf, Switzerland \\ ${ }^{\mathrm{c}}$ Department of Geography, University of Berne, Hallerstrasse 12, CH-3012 Berne, Switzerland \\ ${ }^{\mathrm{d}}$ Cemagref Grenoble, 2 Rue de la Papeterie, B.P. 76, F-38402 Saint Martin d'Hères Cedex, France
}

\begin{abstract}
We used one of the few rockfall models explicitly taking trees into account and compared the results obtained with the 3D simulation model RockyFor with empirical data on tree impacts at three mountain forests in Switzerland. Even though we used model input data with different resolutions at the study sites, RockyFor accurately predicted the spatial distribution of trajectory frequencies at all sites. In contrast, RockyFor underestimated mean impact heights observed on trees at the two sites where high- and medium-resolution input data were available and overestimated them at the site where input data with the lowest resolution data were used. By comparing the results of the simulation scenarios "current forest cover" and "non-forested slope", we assessed the protective effect of the current stands at all three sites. The number of rocks reaching the bottom parts of the study sites would, on average, almost triple if the "current forest cover" were absent.

We conclude that RockyFor is able to predict the spatial distribution of rockfall trajectories on forested slopes accurately, based on input data with a resolution of at least $5 \mathrm{~m} \times 5 \mathrm{~m}$. With the increasing availability of high-resolution data, it provides a useful tool for assessing the protective effect of mountain forests against rockfall.
\end{abstract}

Keywords: Protection forest; Natural hazards; RockyFor; Dendrogeomorphology; Rockfall; 3D simulation model; Swiss Alps

\section{Introduction}

Many mountain forests effectively protect people and their assets against natural hazards such as rockfall, snow avalanches, landslides, debris flows, soil erosion and floods (Brang et al., 2001). As a consequence, numerous settlements and transportation corridors in alpine regions directly depend on the protective effect of these forests and would - at least temporarily - become uninhabitable or inaccessible if this protection were to disappear or become inadequate (Bloetzer and Stoffel, 1998; Agliardi and Crosta, 2003).

In the Swiss Alps, rockfall and snow avalanches comprise the most common hazards, with evidence of rockfall observed in $31 \%$ and moving snow recorded in $37 \%$ of the National Forest Inventory (NFI) plots in mountain forests (Mahrer et al.,

\footnotetext{
* Corresponding author. Tel.: +41 2630090 15; fax: +41 263009746 . E-mail address: markus.stoffel@unifr.ch (M. Stoffel).
}

1988). While the large volumes and high energies occurring with snow avalanches often limit the protective effect of stands (Bartelt and Stöckli, 2001), the small masses that are generally involved in single rockfall events $\left(<5 \mathrm{~m}^{3}\right.$; Berger et al., 2002) allow mountain forests to absorb falling rocks (Leibundgut, 1986; Lafortune et al., 1997; Hétu and Gray, 2000). On forested slopes, both living and dead trees can stop falling rocks (Cattiau et al., 1995), whereas stems lying on the ground or root plates may act as barriers to rocks moving downslope (Mössmer et al., 1994; Schönenberger et al., 2005). Taking advantage of these effects on falling rocks, forest managers repeatedly tried to optimize the protective effect of their forests by applying target values for stand parameters such as tree density, spatial tree distribution, species composition, tree conditions, diameter distribution and basal area (Chauvin et al., 1994; Wasser and Frehner, 1996; Frehner et al., 2005). While these target values undoubtedly provided a valuable tool for forest managers, they currently remain unsatisfactory, since values are predominantly based on expert knowledge rather than on empirical data. 
Empirical data are very sparse, which is why the protective effect of a stand on a given site with a given damage potential could, up to now, only be assessed with considerable uncertainty (Dorren et al., 2005). Given this lack of extensive empirical data on rockfall in mountain forests, dynamic modeling could provide a valuable tool for investigating the protective effect of different stand structures against rockfall and for improving target values for forest management.

To be useful, a model should accurately predict different patterns of rockfall processes such as the spatial envelope of rockfall trajectories, impact heights of rocks, and runout zones. Furthermore, it should be applicable under various site and stand conditions and should consider the interaction of falling rocks with trees - as investigated by Jahn (1988), Zinggeler et al. (1991), Gsteiger (1993), Krummenacher and Keusen (1996), Berger and Lievois (1999) or Dorren et al. (2005) - in sufficient detail.

The recently developed 3D rockfall model RockyFor has accurately predicted different rockfall patterns for several forested and non-forested sites in mountainous terrain (Dorren et al., in press). The model operates with high-resolution input data $(2.5 \mathrm{~m} \times 2.5 \mathrm{~m})$ so as to obtain sound results at the forest stand level. Such data hardly exist for many areas of the Alps. The model has also been shown to predict maximal runout zones with reasonable accuracy, even if based on low-resolution input data, i.e. $25 \mathrm{~m} \times 25 \mathrm{~m}$ (Dorren and Heuvelink, 2004). In contrast, the minimum resolution of input data required to obtain realistic simulation results for other important rockfall features characterizing the protective effect of a stand (e.g. envelope of rockfall trajectories, mean impact height, mean velocity of rocks) is not yet known. Furthermore, even if RockyFor accurately predicted rockfall runout zones and velocities at several sites in France and in Austria, it remains unknown whether it will reliably produce comprehensive results for other sites (Dorren et al., in press).

In this study, RockyFor is applied and evaluated on three different sites in the Swiss Alps with different slope and stand characteristics as well as with data sets of different qualities. The simulated rockfall patterns were then compared with empirical data obtained from the study sites. Finally, we used RockyFor to assess the protective effect of the investigated forest stands by comparing the results of simulation scenarios with and without the current forest cover.

\section{Material and methods}

\subsection{The RockyFor model}

RockyFor is a process-based rockfall simulation model that was originally developed with data obtained from field investigations in the Austrian Alps (Dorren et al., 2004). The model has since been improved and validated with data from 218 real-size rockfall experiments on forested and non-forested slopes in the French Alps (Le Hir et al., 2004; Dorren et al., 2005).

RockyFor uses raster maps as input files and simulates trajectories of falling, bouncing and rolling rocks $(\varnothing<0.5 \mathrm{~m})$ and boulders $(\varnothing>0.5 \mathrm{~m})$ within single raster cells. Moreover, it explicitly simulates the number of rockfall impacts against individual trees and sums them finally per raster cell. The model consists of three main modules. The first module calculates the rockfall trajectory, based on the topography of a site, which is represented by a Digital Elevation Model (DEM). At every step in the simulation, the fall direction of a rock can be towards one of the downslope cells from the cell where the rock is located during that simulation step. Hence, the model produces diverging rockfall trajectories.

The second main module calculates the energy loss due to impacts against single trees. As a result, the exact position of a falling rock and its current energy are modeled. If an impact against a tree takes place, the rock dissipates energy as a function of the relative position between rock and tree center and the stem diameter of the corresponding tree as follows:

$\Delta E=-0.046+\frac{0.98+0.046}{1+10^{\left[0.58-\left(\left(P_{i}-\mathrm{CTA}\right) / 0.5 \mathrm{DBH}\right)-8.007\right]}}$

where $\Delta E$ is the percentage of maximum amount of energy that can be dissipated by the tree $(\%) ; P_{i}-\mathrm{CTA}$, the horizontal distance between the position of the impact and the vertical central axis of the tree as seen from the impact direction (m); $\mathrm{DBH}$, the stem diameter at breast height (m). Thereby, the maximum amount of energy that can be dissipated by a tree (max. E. diss.) is a function of its $\mathrm{DBH}(\mathrm{m})$ as follows:

$\max$. E. diss. $=$ FE_ratio $\times 38.7 \times \mathrm{DBH}^{2.31}$

where max. E. diss. is the maximum amount of energy that can be dissipated by a tree $(\mathrm{kJ})$; FE_ratio, the fracture energy ratio of a given tree species to Abies alba Mill. described by Dorren and Berger (2006); and DBH, the stem diameter at breast height $(\mathrm{cm})$.

The third main module calculates the velocity of the falling rock after a rebound on the slope surface (for details see Dorren et al., 2004). Here, the decrease of velocity after a rebound is mainly dependent on the tangential coefficient of restitution $\left(r_{\mathrm{t}}\right)$, which is determined by the composition and size of the material covering the surface as well as the radius of the falling rock itself (Kirkby and Statham, 1975). The coefficient is calculated as a function of the radius of the rock and the mean radius of the material on the ground as follows:

$r_{\mathrm{t}}=\frac{1}{1+\left(D_{\text {mean }} / D_{\text {rock }}\right)}$

where $D_{\text {mean }}$ is the mean diameter of the material on the slope surface $(\mathrm{m})$ and $D_{\text {rock }}$, the diameter of the falling rock (m). The calculated $r_{\mathrm{t}}$ is uniform randomly varied with $10 \%$ in order to take account: (i) the enormous local variation in the size of material covering rockfall slopes, as well as (ii) the geometry of the falling rock. Furthermore, its value is limited to the range $(0.1,0.99)$ as to avoid unrealistic energy loss (Dorren et al., 2004, in press).

\subsection{Study sites}

RockyFor was applied to three mountain forest sites in different areas of Switzerland. Fig. 1 gives an overview of the sites, while a summary of relevant site characteristics is presented in Table 1. 


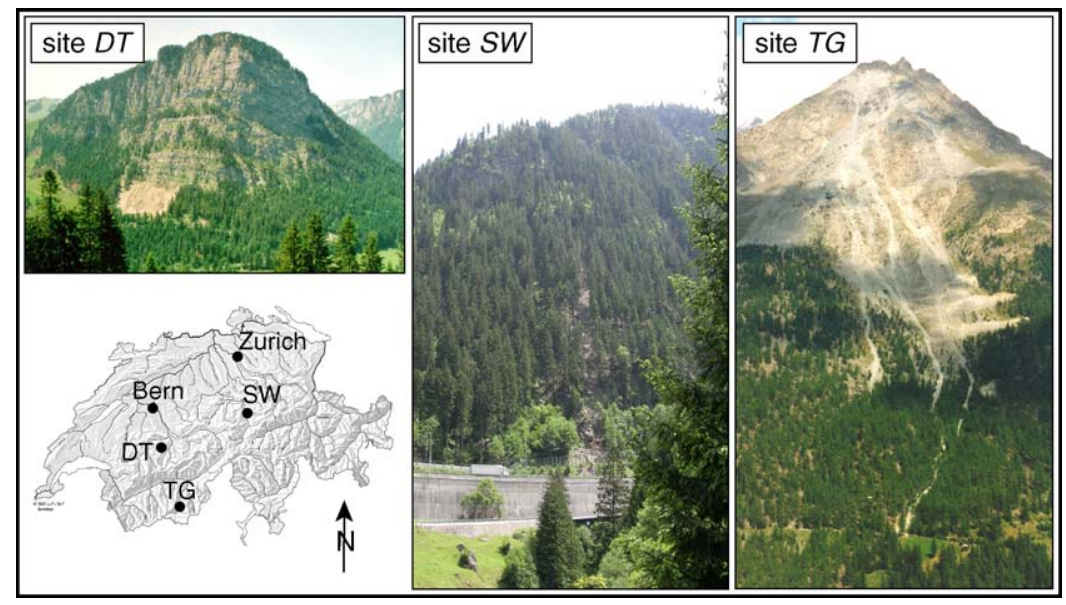

Fig. 1. Localization of the study sites Diemtigtal (site $D T$ ), Stotzigwald (site $S W$ ) and Täschgufer (site $T G$ ) within Switzerland.

The first site is a forest stand in the Diemtigtal (site DT) in the Swiss Prealps. The site lies at the foot of an approximately $400 \mathrm{~m}$ high limestone cliff (Fig. 1) on a southeast exposed talus slope with a mean slope gradient of $40^{\circ}$. The stand is dominated by Picea abies (L.) Karst. (77\%), but other species such as Sorbus aria (L.) Crantz, Sorbus aucuparia L. or Acer pseudoplatanus L. occur as well (23\%). The study site covers $0.3 \mathrm{ha}$, located between 1210 and $1280 \mathrm{~m}$ a.s.l. in the uppermost part of the talus slope. This area is in the transit zone of frequent, but mainly small falling rocks $(\varnothing \sim 0.2 \mathrm{~m})$. Below the study site, hiking trails and forest roads, which could be endangered by rockfall, traverse the slope.

The second site is the Stotzigwald (site $S W$ ), a stand in the central Swiss Alps covering a steep slope with a mean slope gradient of $45^{\circ}$ and some interspersed cliffs (Fig. 1). This forest protects one of the most heavily used traffic routes connecting Germany and Italy. The elevation of the forest ranges from 650 to $1650 \mathrm{~m}$ a.s.l., but rockfall activity is mainly restricted to a zone of approximately 7.5 ha in the lower part of the forest, i.e. up to approximately $1000 \mathrm{~m}$ a.s.l. The stand within this zone mainly consists of Picea abies (83\%) and Abies alba (13\%). The slope is covered with rocks, boulders and morainic material. Bedrock consists of heavily weathered granite and gneiss. As a result, rockfall frequently occurs and rocks regularly reach the highway.

The third site is Täschgufer (site $T G$ ), which is located in the southern Swiss Alps (Fig. 1). Here, rockfall is frequently triggered from the heavily disintegrated paragneissic rockwalls below the Leiterspitzen summit (3214 $\mathrm{m}$ a.s.l.). In the upper part of the site, which covers 26 ha, mean slope gradients reach $48^{\circ}$ and gradually decrease to $20^{\circ}$ near the valley floor $(1430 \mathrm{~m}$ a.s.l.). In the central area affected by rockfall, continuous forest cover reaches $1780 \mathrm{~m}$ a.s.l., whereas the upper part of the slope remains mostly free of vegetation. The stand predominantly consists of Larix decidua Mill. (95\%), accompanied by single Picea abies and Pinus cembra ssp. sibirica. In the recent past, rockfall regularly reached the valley floor, causing damage to roads, hiking trails and agricultural buildings.

\subsection{Model input data}

For all sites, extensive data on stand structure, geomorphological characteristics and rockfall patterns were available from earlier field studies. In addition, dendrogeomorphological data on century-long fluctuations in rockfall activity exist for site $T G$. A summary of all input data used for the simulation with RockyFor is presented in Table 2.

In addition to the pre-existing data, complementary data on different site characteristics were gathered in the field (Kühne, 2005): Firstly, potential rockfall source areas were mapped, integrated into a Geographical Information System (GIS) and converted to raster maps. Secondly, terrain and vegetation parameters were mapped and polygons with homogeneous terrain characteristics described. From this data, a raster map was created for the normal coefficient of restitution $\left(r_{\mathrm{n}}\right.$; cf. Dorren and Seijmonsbergen, 2003) and for the mean diameter of the material covering the slope surface. The latter was required to calculate the tangential coefficient of restitution $\left(r_{\mathrm{t}}\right)$.

In a third step, complementary data on stand structure and empirical rockfall patterns were gathered on validation plots of approximately $225 \mathrm{~m}^{2}(15 \mathrm{~m} \times 15 \mathrm{~m})$ at sites $S W$ and $T G$ so as to provide: (i) data on the tree diameter distribution and (ii) validation data for the simulation experiments. On these

Table 1

Characteristics of the three study sites

\begin{tabular}{|c|c|c|c|c|}
\hline Study site (area) & $\begin{array}{l}\text { Altitudinal range } \\
\text { (m a.s.l.) }\end{array}$ & Mean slope $\left({ }^{\circ}\right)$ & $\begin{array}{l}\text { Stand characteristics } \\
\text { (main tree species, tree density, mean DBH) }\end{array}$ & $\begin{array}{l}\text { Predominating size of rocks } \\
\text { (mean diameter }[\mathrm{m}] \text { ) }\end{array}$ \\
\hline Diemtigtal (DT) 0.3 ha & $1210-1280$ & 40 & Picea abies, 520 trees ha $^{-1}, 21 \mathrm{~cm}$ & 0.2 \\
\hline Stotzigwald (SW) 7.5 ha & $650-1000$ & 45 & Picea abies, Abies alba, 561 trees ha ${ }^{-1}, 38 \mathrm{~cm}$ & 0.7 \\
\hline Täschgufer (TG) 26 ha & $1430-3214$ & $20-48$ & Larix decidua, 150 trees $\mathrm{ha}^{-1}, 30 \mathrm{~cm}$ & 0.9 \\
\hline
\end{tabular}


Table 2

Data used for the simulation experiments

\begin{tabular}{|c|c|c|c|c|}
\hline Feature class & Available data & Sampling method & Source & Derived model input \\
\hline \multirow[t]{3}{*}{$\begin{array}{l}\text { Stand } \\
\text { structure }\end{array}$} & Species composition & $\begin{array}{l}\text { Inventory sampling procedure } \\
\text { on stand plots }\end{array}$ & $\begin{array}{l}\text { Perret et al. (2004), Wehrli et al. } \\
\text { (submitted), Stoffel et al. (2005a,b) }\end{array}$ & Stand raster map \\
\hline & Diameter distribution & $\begin{array}{l}\text { Inventory sampling procedure } \\
\text { on stand plots }\end{array}$ & $\begin{array}{l}\text { Kühne (2005), Perret et al. (2004), } \\
\text { Wehrli et al. (submitted), } \\
\text { Schneuwly (2003) }\end{array}$ & \\
\hline & Tree density & Analysis of aerial photographs & Kühne (2005), Perret et al. (2004) & \\
\hline \multirow[t]{2}{*}{$\begin{array}{l}\text { Surface } \\
\quad \text { roughness }\end{array}$} & $\begin{array}{l}\text { Granular composition of } \\
\text { surface material }\end{array}$ & $\begin{array}{l}\text { Estimation in five classes } \\
(<0.2 \mathrm{~m}, 0.2-0.5 \mathrm{~m}, 0.5-1 \mathrm{~m}, 1-2 \mathrm{~m},>2 \mathrm{~m})\end{array}$ & Kühne (2005) & $r_{\mathrm{t}}$-Raster map \\
\hline & Vegetation cover & Estimation of proportion of bushes and shrubs & Kühne (2005) & \\
\hline $\begin{array}{r}\text { Subsurface } \\
\text { damping }\end{array}$ & $\begin{array}{l}\text { Damping properties of } \\
\text { subsurface }\end{array}$ & $\begin{array}{l}\text { Estimation in six classes } \\
\text { (bedrock, scree/talus, stony soil, } \\
\text { dry forest soil, fine humid soil) }\end{array}$ & Kühne (2005) & $r_{\mathrm{n}}$-Raster map \\
\hline \multirow[t]{2}{*}{ DEM } & Laser scan data (site DT) & $\begin{array}{l}\text { Interpolation to raster using } \\
\text { Spatial Analyst (ESRI 2005) }\end{array}$ & $\begin{array}{l}\text { DTM-AV C } 2004 \text { Swisstopo } \\
\text { (DV033531) }\end{array}$ & DEM \\
\hline & $\begin{array}{l}\text { Aerial photographs } \\
\text { (sites SW \& TG) }\end{array}$ & $\begin{array}{l}\text { Deriving contour lines from } \\
\text { aerial photographs and interpolation to } \\
\text { raster using Spatial Analyst (ESRI 2005); } \\
\text { surface points and breakline features assessed } \\
\text { with ERDAS Stereo Analyst (Leica, 2005) }\end{array}$ & $\begin{array}{l}\text { DEM C } 2004 \text { WSL, P. Thee } \\
\text { (site SW) DEM C } 2005 \text { GIUB, } \\
\text { R. Kühne (site TG) }\end{array}$ & \\
\hline $\begin{array}{l}\text { Rock } \\
\text { properties }\end{array}$ & Rock size & $\begin{array}{l}\text { Estimation of rock size description of recent } \\
\text { accumulation (three granular classes) }\end{array}$ & Kühne (2005) & Rock size \\
\hline \multirow[t]{2}{*}{$\begin{array}{l}\text { Validation } \\
\text { data }\end{array}$} & $\begin{array}{l}\text { Number of tree impacts } \\
\text { due to rockfall }\end{array}$ & $\begin{array}{l}\text { Count of tree injuries due to } \\
\text { rockfall in test plots }\end{array}$ & Kühne (2005), Perret et al. (2004) & $\begin{array}{l}\text { Validation raster } \\
\text { map }\end{array}$ \\
\hline & $\begin{array}{l}\text { Mean and max. impact } \\
\text { heights }\end{array}$ & Assessment of $h_{\max }, h_{\text {mean }}$ & $\begin{array}{l}\text { Kühne (2005), Perret et al. (2004), } \\
\text { Schneuwly (2003), Stoffel et al. (2005a,b) }\end{array}$ & \\
\hline
\end{tabular}

validation plots, DBH was therefore measured for all individual trees with a DBH $\geq 8 \mathrm{~cm}$. Rock impacts were assessed on the stem surface of trees, and the mean and maximum impact heights measured on every single tree. In order to derive forest stand maps as needed by RockyFor, field data were coupled with a tree distribution map obtained from photogrammetric analyses, where every individual tree crown was mapped on orthophotos (scale 1:9000). For site $D T$, no complementary data on stand and rockfall patterns were gathered, since data for every single tree on the site were available.

Finally, high resolution Digital Elevation Models (DEM) of $1 \mathrm{~m} \times 1 \mathrm{~m}$ (site $D T$ ) and $5 \mathrm{~m} \times 5 \mathrm{~m}$ (sites $S W$ and $T G$ ) were produced. For site $D T$, we created a DEM by interpolating LIDAR (LIgth Detection And Ranging-Laser Scanning) point data delivered by the Swiss Topographical Service (Swisstopo, 2004) that represent the ground surface. The applied interpolation method was Ordinary Kriging using on average 12 points per raster cell. For site $S W$, the DEM was derived from contour lines (equidistance: $12.5 \mathrm{~m}$ ) created on the basis of photogrammetric analyses realized with high quality aerial photographs (scale 1:9000). At site $T G$, in contrast, surface points and breakline features were generated from orthophotos (scale 1:9000) and coupled with $10 \mathrm{~m}$ contour lines digitized from a topographic map in a scale of 1:10,000.

\subsection{Simulation set-up}

Since RockyFor models rockfall on the basis of various stochastic algorithms, at least 100 simulation runs from each potential rockfall source cell were needed to obtain sufficiently stable results (Dorren and Heuvelink, 2004). In the first simulation run, one rock was released from each defined rockfall source cell, one after another, which means that the trajectory of each rock has been calculated individually. This process was then repeated 99 times. Thus, from a cliff that consists of 200 rockfall source cells, 20,000 rocks, and consequently different trajectories and velocities will be simulated.

To account for the varying size of falling rocks and boulders at the three sites, we simulated varying numbers of rocks for each size class (cf. Table 4). The selected number of simulations per size class was derived from estimates in the field and represents the diameter size distribution of rocks at the three sites.

The initial fall height of the rocks for the simulation experiments was set to $30 \mathrm{~m}$ at site $D T$, to $5 \mathrm{~m}$ at site $S W$ and to $3 \mathrm{~m}$ at site $T G$. These values were determined by the morphology of the rockfall source areas and they correspond to the mean height of vertical cliff faces in the source areas of 
the three sites. Simulation runs were first realized on the slopes with the "current forest cover", before trees were removed in the "non-forested" scenario and simulation runs repeated.

\subsection{Assessment of model accuracy}

Simulated and empirical rockfall patterns were compared on the basis of: (i) the spatial distribution of rockfall impacts on trees, which is an indicator for the spatial distribution of the rockfall trajectories and (ii) mean impact heights, which are indicators for bounce heights of rocks. To compare the simulation results with empirical values, we used the arithmetric mean per cell of the calculated variable taking into account all the simulation runs, since one simulation run cannot reproduce the data gathered in the terrain. At site $D T$, the accuracy of the model was assessed at the level of single trees, since detailed data were available (Perret et al., in press-a, in press-b). At sites $S W$ and $T G$, however, the analysis was performed on validation plots of $225 \mathrm{~m}^{2}$ (see Section 2.3). At site $T G$, simulation results were also compared with data on spatio-temporal variations in rockfall activity derived from dendrogeomorphological analysis of 129 living trees for the last 400 years (Stoffel et al., 2005b).

The number of rockfall impacts per tree was directly assessed from the empirical data for site $D T$. For sites $S W$ and $T G$, a tree impact coefficient (TIC) was calculated as:

$\mathrm{TIC}=\frac{\text { TreeHits }_{j}}{n_{\text {Trees }, j}}$

where TreeHits $_{j}$ is the sum of tree impacts per validation plot $j$, and $n_{\text {Trees }, j}$, the number of trees in validation plot $j$. For standardization purposes, both empirical and simulated data were expressed as proportions relative to the summed values over all trees (site $D T$ ), and over all validation plots (sites $S W$ and $T G)$, respectively.

The mean impact height was calculated for every single tree (site $D T$ ) and for every validation plot (sites $S W$ and $T G$ ). At site $T G$, impact heights were also integrated from century-old Larix decidua trees analyzed with dendrogeomorphological methods (Stoffel et al., 2005b). While tree-ring analysis yielded data on 786 rockfall impacts since 1394 AD, scars remained recognizable on the stem surface in less than $10 \%$ of all cases (Stoffel and Perret, submitted), mainly representing relatively recent or unusually large evidence of past rockfall events.
In a subsequent step, mean (ME) and root mean-squared errors (RMSE) between the predicted and the observed number of impacts and mean impact heights were calculated as follows:

$\mathrm{ME}=\frac{1}{n} \sum_{i=1}^{n}\left(P_{i}-O_{i}\right)$

$\mathrm{RMSE}=\sqrt{\frac{1}{n} \sum_{i=1}^{n}\left(P_{i}-O_{i}\right)^{2}}$

where $n$ is the number of trees (site $D T$ ) or validation plots (sites $S W$ and $T G) ; P_{i}$, the predicted (i.e. simulated) and $O_{i}$, the observed rock impacts at tree $i$ (site $D T$ ) and validation plot $i$ (sites $S W$ and $T G$ ).

Furthermore, the proportional difference between the predicted and the observed number of impacts was calculated for each tree (site $D T$ ) and each validation plot (sites $S W$ and $T G$ ), and then illustrated for deviations $\geq 2.5 \%$ and $\geq 5 \%$. Thus, the simulated trajectories of all size classes of rocks were summed and compared with the empirical patterns.

\subsection{Assessment of the protective effect of the different stands}

The protective effect of the stands was then assessed at the three sites by quantifying changes in the frequency of simulated rockfall trajectories between the scenarios "current forest cover" and "non-forested slope". Differences were assessed in "evaluation zones" at the foot of every test slope where high damage potential exists (i.e. roads or buildings). We defined these zones in a vector map, which was subsequently transformed into a raster map. We then compared the number of rocks that entered the "evaluation zones" in the simulated raster maps containing the stopping positions of the rocks as produced by the two modeling scenarios. This has been done for all the simulated diameter classes. The difference between the two scenarios has been quantified by the following ratio:

$\mathrm{RF}_{\text {ratio }} i=\frac{\mathrm{PR}_{\text {non-forested_slope }, i}}{\mathrm{PR}_{\text {forested_slope }, i}}$

where $\mathrm{PR}_{\text {non-forested_slope }, i}$ and $\mathrm{PR}_{\text {forested_slope }, i}$ are the number of rocks per diameter class $i$ passing the evaluation zone on the non-forested and forested slope, respectively. Furthermore, the protective effect of the two scenarios was compared graphically after summing the simulated trajectories over all diameter classes of rocks.

Table 3

Mean (ME) and root mean-squared errors (RMSE) between observed number of tree hits and impact heights $\left(h_{\text {mean }}\right)$ and model results obtained at study sites $D T, S W$, $T G$ dataset 1 and $T G$ dataset 2 (for explanation see text)

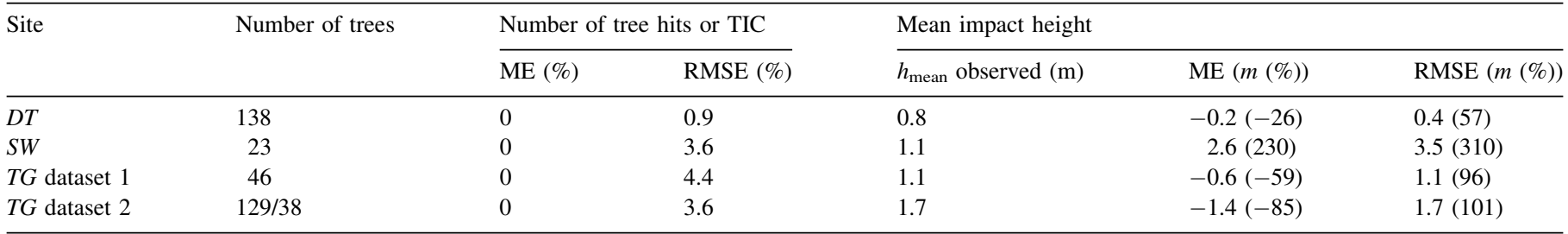




\section{Results}

\subsection{Model accuracy}

In general, the simulation experiments yielded very close matches between simulated and empirical spatial distributions of tree impacts on all three sites. However, for mean impact heights, the correspondence between simulated and observed data varied considerably.

At site $D T$, the simulated number of tree hits corresponds well with the empirical data, as indicated by the RMSE of $0.9 \%$ (Table 3). Fig. 2a shows that differences predominantly occur in the uppermost sector of the study site, where the model overestimates the number of hits in nine trees by +2.5 and $+5 \%$. On the southwestern edge of the study site, the model, in contrast, underestimates the number of impacts in one tree by more than $-5 \%$. For the remaining 128 trees (93\%), differences between the predicted and the observed number of tree hits remain between $\pm 2.5 \%$. On the other hand, differences can be seen with impact heights, where RockyFor underestimates the mean impact height by $-0.21 \mathrm{~m}$ (ME) and $0.46 \mathrm{~m}$ (RMSE). As can be seen from Table 3, deviations from the observed mean impact height $(0.85 \mathrm{~m})$, therefore, account for $26 \%$ (ME) and $57 \%$ (RMSE).

At site $S W$, the predicted tree impact coefficient (TIC) pattern matches the empirical data from the validation plots with a RMSE of 3.6\% (Table 3). As illustrated in Fig. 2b, the model more commonly overestimates the number of tree hits, but underestimates occur as well. Differences exceeding $\pm 5 \%$ are identified in four validation plots $(17 \%)$ and prediction errors ranging from $2.5 \%$ to $5 \%$ are present in six plots $(26 \%)$. In the other 13 validation plots (i.e. 57\%), the difference between the predicted and the observed number of tree hits remains within a range of $\pm 2.5 \%$. As shown in Table 3, RockyFor overestimates, in contrast, mean impact heights with a ME of $+2.6 \mathrm{~m}$ and a RMSE of $3.5 \mathrm{~m}$. Compared to the mean impact height of $1.1 \mathrm{~m}$ observed in the field, this corresponds to an overestimation of $210 \%$ (ME) and 310\% (RMSE), respectively.

At site $T G$, simulated rockfall data are compared with data gathered on 46 validation plots in the field (TG dataset 1 ) as well as with results from dendrogeomorphological reconstructions of past rockfall activity ( $T G$ dataset 2 ). As indicated in Table 3, the model again accurately predicts the empirical TIC pattern with a RMSE of $4.4 \%$ for $T G$ dataset 1 and $3.6 \%$ for $T G$ dataset 2. For $T G$ dataset 1 , underestimation occurs in eight validation plots $(17 \%)$ with differences between the observed and the predicted number of tree impacts primarily remaining between $-2.5 \%$ and $-5 \%$. For $T G$ dataset 2 , in contrast, overestimation can be observed in seven out of 129 validation plots $(5 \%)$, mostly exceeding $+5 \%$, whereas underestimation can only be found in one plot $(1 \%)$. Interestingly, the overestimated validation plots are concentrated along the upper fringe of the continuous forest stand and near the rockfall channel, as shown in Fig. 2c. Results also indicate that in $80 \%$ (TG dataset 1) and $94 \%$ (TG dataset 2) of the validation plots, differences between simulated and predicted TIC patterns remain within a range of $\pm 2.5 \%$.
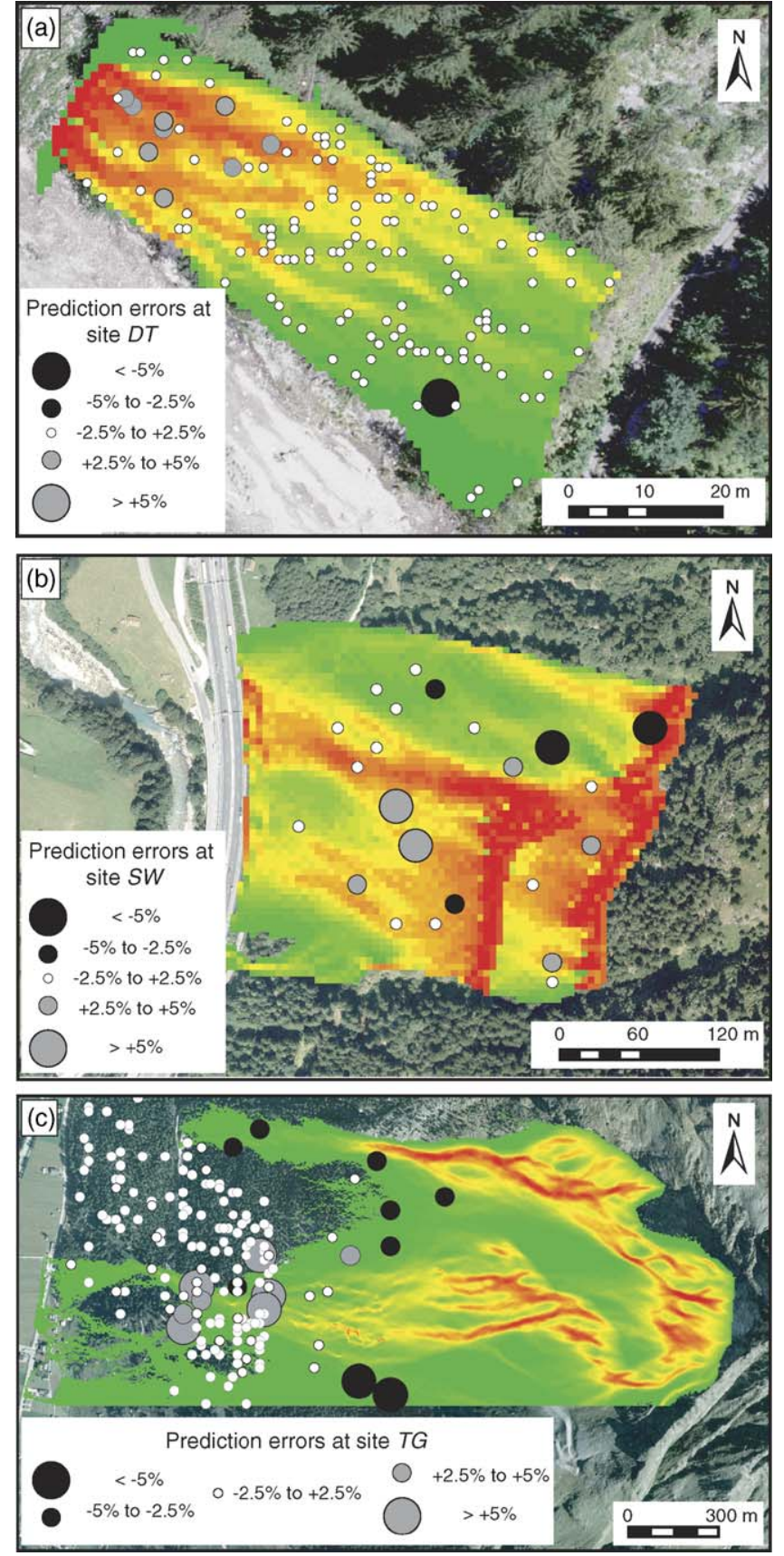

Fig. 2. Differences between simulated and observed number of rock impacts on trees or validation plots at: (a) site $D T$, (b) site $S W$ and (c) site $T G$. Gray circles indicate an overestimation by the model, whereas black circles show underestimation. White circles represent trees or validation plots with a very similar number of rock impacts for simulations and observations $( \pm 2.5 \%)$ (orthophoto sources: site DT: (C) Baumgartner (2002); site $S W$ : (C) Kanton Uri; site $T G$ : (C) 2005 swisstopo (BA056895).

In contrast, we observed a difference between the empirical and simulated impact heights. For $T G$ dataset 1 , the model underestimates the mean impact height observed in the field $(1.1 \mathrm{~m})$ with a ME of $-0.6 \mathrm{~m}$ and a RMSE of $1.1 \mathrm{~m}$. As can be seen from Table 3, this corresponds to a relative underestimation of $59 \%$ and $96 \%$, respectively. For $T G$ dataset 2 , the observed mean impact height $(1.7 \mathrm{~m})$ is underestimated with a ME of $-1.4 \mathrm{~m}(85 \%)$ and a RMSE of $1.7 \mathrm{~m}(101 \%)$. 
Table 4

Assessment of the protective effect of the investigated stands

\begin{tabular}{|c|c|c|c|c|c|c|c|c|c|c|c|c|c|c|}
\hline \multirow{2}{*}{$\begin{array}{l}\text { Site start } \\
\text { cells }\end{array}$} & \multirow{2}{*}{$\begin{array}{l}\text { Forest } \\
\text { cover }\end{array}$} & & \multicolumn{12}{|c|}{ Diameter of RF (m) } \\
\hline & & & 0.1 & 0.2 & 0.3 & 0.4 & 0.6 & 0.8 & 1 & 1.2 & 1.4 & 1.6 & 1.8 & 2 \\
\hline $\begin{array}{l}\text { Site } D T \text { start } \\
\text { cells } 12\end{array}$ & $\begin{array}{l}\text { Forested } \\
\text { Non-forested }\end{array}$ & $\begin{array}{l}\text { RF triggered } \\
\text { Passing RF (\%) } \\
\text { Passing RF (\%) } \\
\text { RF_ratio }\end{array}$ & $\begin{array}{c}1500 \\
0.7 \\
6 \\
8.5\end{array}$ & $\begin{array}{r}2000 \\
5.2 \\
18.1 \\
3.5\end{array}$ & $\begin{array}{r}1500 \\
13 \\
32.4 \\
2.5\end{array}$ & - & - & - & - & - & - & - & - & - \\
\hline $\begin{array}{c}\text { Site } S W \text { start } \\
\text { cells } 331\end{array}$ & $\begin{array}{l}\text { Forested } \\
\text { Non-forested }\end{array}$ & $\begin{array}{l}\text { RF triggered } \\
\text { Passing RF (\%) } \\
\text { Passing RF (\%) } \\
\text { RF_ratio }\end{array}$ & - & $\begin{array}{r}1200 \\
1.5 \\
3.9 \\
2.5\end{array}$ & - & $\begin{array}{r}1500 \\
3 \\
6.8 \\
2.3\end{array}$ & $\begin{array}{r}1200 \\
5.2 \\
8.8 \\
1.7\end{array}$ & $\begin{array}{r}1000 \\
5.7 \\
9.5 \\
1.7\end{array}$ & $\begin{array}{r}600 \\
6.7 \\
15.8 \\
2.4\end{array}$ & $\begin{array}{r}500 \\
7.9 \\
9.9 \\
1.3\end{array}$ & $\begin{array}{r}200 \\
8.4 \\
9.9 \\
1.2\end{array}$ & $\begin{array}{r}200 \\
8.8 \\
9.9 \\
1.1\end{array}$ & $\begin{array}{c}100 \\
8.7 \\
9.9 \\
1.1\end{array}$ & $\begin{array}{c}100 \\
8.7 \\
9.9 \\
1.1\end{array}$ \\
\hline $\begin{array}{r}\text { Site } T G \text { start } \\
\text { cells } 7692\end{array}$ & $\begin{array}{l}\text { Forested } \\
\text { Non-forested }\end{array}$ & $\begin{array}{l}\text { RF triggered } \\
\text { passing RF (\%) } \\
\text { passing RF (\%) } \\
\text { RF_ratio }\end{array}$ & - & $\begin{array}{r}1200 \\
0 \\
0 \\
0\end{array}$ & - & $\begin{array}{r}1500 \\
0 \\
0 \\
0\end{array}$ & $\begin{array}{r}1200 \\
0 \\
0 \\
0\end{array}$ & $\begin{array}{c}1100 \\
\quad 0.001 \\
0.004 \\
4.5\end{array}$ & $\begin{array}{c}1000 \\
0.002 \\
0.011 \\
6.7\end{array}$ & $\begin{array}{l}800 \\
\quad 0.003 \\
0.018 \\
5.5\end{array}$ & $\begin{array}{l}700 \\
0.006 \\
0.026 \\
4.1\end{array}$ & $\begin{array}{l}600 \\
0.011 \\
0.043 \\
4.1\end{array}$ & $\begin{array}{l}500 \\
\quad 0.035 \\
0.076 \\
2.2\end{array}$ & $\begin{array}{l}400 \\
0.057 \\
0.107 \\
1.9\end{array}$ \\
\hline
\end{tabular}

The number of rockfall fragments (RF) triggered per diameter class and start cell is given as $n$. The percentage of rocks and boulders passing the evaluation zones is given for the scenarios "forested slope" and "non-forested slope" and the differences between the two scenarios expressed with a RF_ratio (for explanation see text).

\subsection{Protective effect}

The comparison between the two simulation scenarios "current forest cover" and "non-forested slope" yielded significant differences for all three sites. Table 4 first of all shows that the number of rocks and boulders passing the evaluation zones was considerably higher in the "nonforested" scenario.

At site $D T$, the complete removal of the forest stand would result in more rocks passing the evaluation zone at the foot of the study site, as indicated by the high RF_ratios between the two scenarios. As can be seen from Table 4, this is particularly true for the smallest rock diameter class $(0.1 \mathrm{~m})$ used in the simulation runs, for which the RF_ratio increased by a factor of 8.5 , as compared to the scenario with the "current forest cover". Fig. 3 gives a qualitative impression of the differences emerging between the two scenarios, indicating that the increase in the transit of rocks is most obvious in the northeastern and central parts of the study site. In contrast, negative effects appear to be less drastic in the southern half, where frequencies only slightly increased in the "nonforested" scenario.

At site $S W$, the number of rocks passing the evaluation zone is rather high in both scenarios. As shown in Table 4, differences between the two scenarios are most obvious for rocks and small boulders of up to $1 \mathrm{~m}$ in diameter, where RF_ratios varied between a factor of 1.7 and 2.5. Fig. 3 illustrates that in the "non-forested" scenario, a considerable increase in the number of rockfall trajectories can be observed below the subvertical cliff in the central part of the study site. Results also indicate that in the scenario with the "current forest cover", rocks originating from this cliff would be partly stopped through the presence of trees, whereas the absence of trees would allow most rocks and boulders to travel down the slope and reach the adjacent highway. A similar protective effect of the stand is evident for rocks originating from the uppermost cliff area.
In contrast to sites $D T$ and $S W$, Table 4 indicates that the differences in the number of rocks and boulders passing through the evaluation zone at site $T G$ are considerably smaller for most diameter classes. Nonetheless, significant differences arise between the two scenarios for boulders with diameters $>0.8 \mathrm{~m}$, as indicated by the high RF_ratios in Table 4 . The qualitative comparison of the scenarios in Fig. 3 indicates a minor increase in the number of rocks passing down the slope in the rockfall channel located in the northwestern part of the study site, where the number of deposited rocks and boulders doubles in some locations. In the central part of the study site, rockfall activity increases as well, meaning that boulders would more frequently reach the main road in the valley floor (Fig. 3).

\section{Discussion}

\subsection{Model accuracy}

In the study we report here, the 3D rockfall simulation model RockyFor was tested and its capability to accurately predict rockfall patterns assessed at three forested sites in the Swiss Alps. Overall, the comparison of observed with simulated rockfall patterns yielded a high correspondence for the spatial distribution of tree impacts and a low correspondence for the mean impact heights.

The closest match between empirical and simulated distributions of tree impacts was obtained at site $D T$, where a highly resolved DEM $(1 \mathrm{~m} \times 1 \mathrm{~m})$ allowed very accurate modeling of rockfall trajectories. At sites $S W$ and $T G$, the simulation based on a $5 \mathrm{~m} \times 5 \mathrm{~m}$ DEM derived from contour lines with an equidistance of $12.5 \mathrm{~m}$ (site $S W$ ) and $10 \mathrm{~m}$ (site $T G$ ) still yielded close matches between the empirical and predicted distribution of tree impacts with RMSE $\leq 4.4 \%$. As stochastic elements are involved in rockfall processes, a complete agreement of empirical and simulated trajectories is unlikely, which is why we believe that for an accurate prediction of the spatial envelope of rockfall trajectories, a 


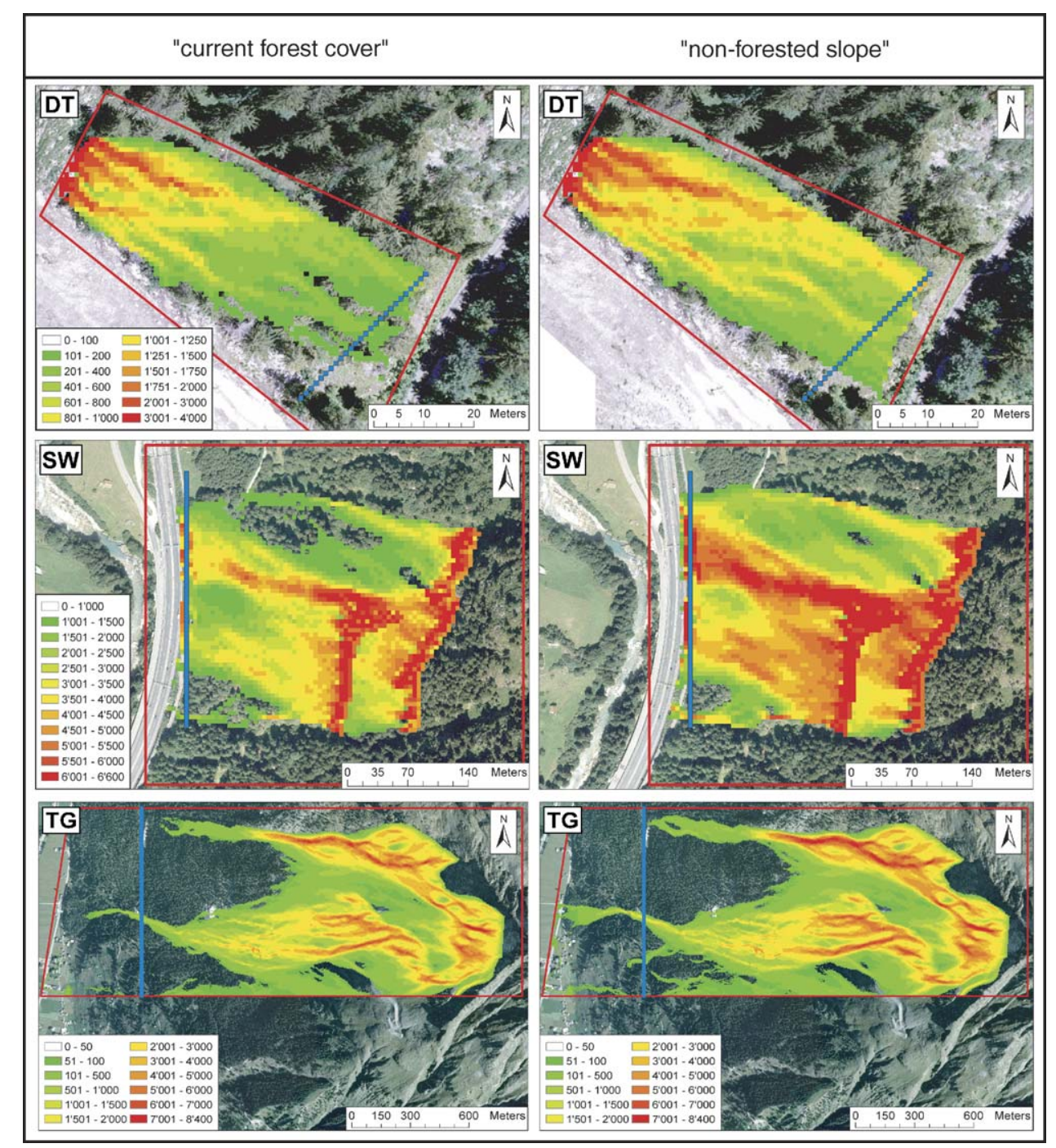

Fig. 3. Comparison of simulated rockfall trajectories for the "current forest cover" (left) and for the "non-forested slope" (right) at: (a) site DT, (b) site $S W$ and (c) site $T G$. Evaluation zones are indicated with blue lines.

DEM with a resolution of $5 \mathrm{~m} \times 5 \mathrm{~m}-$ as used at sites $S W$ and $T G-$ is largely sufficient.

In contrast to the spatial distribution of rockfall trajectories, the prediction of mean impact heights was less accurate. Even at site $D T$, predicted mean impact heights were considerably lower than the values observed in the field. This low correspondence is particularly surprising, since RockyFor produced close matches between empirical and simulated mean impact heights for a site in the French Alps, based on a DEM with a resolution of $2.5 \mathrm{~m} \times 2.5 \mathrm{~m}$ (Dorren et al., submitted for publication). The underestimation of mean impact heights further increased at site $T G$, where the model produced a negative bias for both $T G$ dataset 1 and $T G$ dataset 2 . In contrast, RockyFor largely overestimated mean impact heights at site $S W$.

The reasons for the poor correspondence between the predicted and the observed mean impact heights may be manifold. Since RockyFor was calibrated on the basis of more than 200 real-size experiments (Dorren et al., 2005) and different rockfall patterns, including mean impact heights accurately predicted before, we believe the main reasons for the rather low agreement between empirical and simulated mean impact heights to be model-independent rather than modelintrinsic.

A first factor that might have affected the accuracy of the simulation results is the DEM, i.e. its spatial resolution. This is particularly true for sites $S W$ and $T G$, where DEMs were derived from contour lines with relatively low resolution. Consequently, micro-topographical structures are neglected in the DEM, which in turn can influence the velocity of falling rocks. For instance, huge boulders from ancient rockslide deposits could not be included in the DEM at site $T G$. These boulders may, however, cause rocks to bounce and therefore produce higher impacts than suggested by the model. At site $S W$, the rather coarse DEM was probably the main reason for the large overestimation of the mean impact height, since on this steep slope with an average inclination of $45^{\circ}$, the frequently occurring, abrupt changes in the slope gradient could probably not be reproduced in the DEM with sufficient accuracy. These observations are in agreement with 
Agliardi and Crosta (2003), who report a decrease in bounce height in the flatter parts of the slope and an increase in bounce height on steeper slopes as soon as the resolution of support data decreases. When using a $5 \mathrm{~m} \times 5 \mathrm{~m} \mathrm{DEM}$, it would, therefore, be preferable if the underlying data had a support of at least five meters as well (e.g., 1-5 m contour lines or LIDAR data), so as to take essential terrain features into account.

A second factor influencing the mean impact height in the model can be identified in the uncertainty related to the delineation of rockfall source areas and initial fall heights. Within the present study, we determined rockfall source areas based on observations and geological advisory opinions. A large number of rocks were triggered from these start cells with a given initial fall height, which again was determined based on qualitative field observations. It is, however, clear that these observations can only be seen as an approximation to reality, since precise determination of rockfall source areas and initial fall heights was rendered impossible by complex terrain features such as the $400 \mathrm{~m}$ high limestone cliff at site $D T$, or subvertical cliffs at site $S W$. Nonetheless, a more precise assessment of the rockfall source areas and the initial fall heights seem to be decisive for a better prediction of bounce heights of rocks and, consequently, impact heights on trees.

A third factor affecting modeled impact heights is represented by the validation datasets, which were mainly based on the assessment of impact scars visible on the stem surface of trees. As previously shown by Stoffel (2005, in press), scars as evidence of past rockfall events may become completely blurred with time and are, as a consequence, no longer visible on the stem surface. On the other hand, it is also conceivable that large scars caused by high-energy impacts at unusually high positions may persist for a long time on the stem surface, and therefore lead to an overestimation of rare impact heights. Nonetheless and as half of the scars caused through the action of large rocks $(\varnothing 0.8 \mathrm{~m})$ prove to be no longer visible on the stem surface of Larix decidua Mill. after as little as 20 years (Stoffel and Perret, submitted), we believe that our field observations of impact heights and trajectory frequencies accurately illustrate the recent rockfall activity occurring in the current forest stands. Furthermore, the accuracy of the validation datasets was also influenced by the tree species and the age of single trees. At site $T G$, for instance, the overestimated plots illustrated in Fig. 2c largely occur in areas where juvenile trees are recolonizing the slope. In contrast to their older neighbors, these trees only show a comparably low number of scars in the field, as there has not been sufficient time for scarring.

Other factors such as the small number of test plots for site $S W$ or minor inaccuracies in the $r_{\mathrm{t}} / r_{\mathrm{n}}$-maps may have influenced the prediction of mean impact heights as well, but the three factors mentioned above are probably of prime importance. Nevertheless, model results clearly indicate that the $3 \mathrm{D}$ process-based model RockyFor is able to accurately predict the spatial envelope of rockfall trajectories based on input data with a resolution of $5 \mathrm{~m} \times 5 \mathrm{~m}$.

\subsection{Protective effect}

The second aim of this study was to assess the protective effect of the investigated stands against rockfall through a comparison of simulation scenarios with the "current forest cover" and on a "non-forested slope". This allowed quantification of the protective effect of the forest stands at the three sites, as indicated by the RF_ratios between the scenarios.

The protective effect of the stands is highest for rocks and small boulders (diameter $\leq 1 \mathrm{~m}$ ) at sites $D T$ and $S W$ (cf. Table 4). Here, the number of rocks passing through the evaluation zones is between 1.7- and 8.5-times higher in the "non-forested" scenario, indicating an effective protective function of the current stands. At site $T G$, the stand seems, in contrast, to protect objects at risk from (large) boulders ranging from $0.8 \mathrm{~m}$ to $2 \mathrm{~m}$ in diameter rather than from smaller rocks. Even though rocks passing through the evaluation zone appear to occur much less frequently here, the protective effect of the stand should not be discounted.

We therefore think that at all three sites, the hazard potential would increase strongly without the current stands: At site $D T$, rocks would more frequently reach the forest road and endanger the nearby hiking trails, whereas at sites $S W$ and $T G$, important infrastructure would be endangered (site $S W$ : highway, site $T G$ : main road, buildings). Given the high damage potential at sites $S W$ and $T G$, several countermeasures have been taken in the recent past. At site $S W$, restraining nets have been constructed along the highway, whereas at site $T G$, seven dams have been built on the slope. As evident from our simulation results, these countermeasures are more than justified.

\section{Conclusions}

This study clearly showed that, based on input data with a resolution of at least $5 \mathrm{~m} \times 5 \mathrm{~m}$, RockyFor is able to accurately predict the spatial distribution of rockfall trajectories on forested sites with different slope and stand characteristics. In contrast, we were unable to confirm an accurate prediction of mean impact heights in the present. We believe that high-resolution input data including e.g., a laser scan based DEM, a better knowledge of rockfall source areas, and data on initial fall heights would considerably improve the quality of the predicted impact heights. In addition, the use of dendrogeomorphological analyses increases the amount and quality of validation data and should be used more systematically in rockfall forest research.

Due to its ability to accurately predict the spatial envelope of rockfall trajectories, the present version of RockyFor also provides a valuable research tool for investigating the protective effect offered by different stand structures.

\section{Acknowledgements}

We are grateful to the European Commission for the Marie Curie Fellowship (QLK5-CT-2002-51705). Additional funding was provided by the Swiss National Science Foundation (grant 4048-064409) and the Swiss Forest Agency. We kindly acknowledge Marc Baumgartner, Catherine Berger, Monika 
Fässler, Connie Hett, Dominique Schneuwly and Mathias Zesiger for assistance in the field. Igor Lièvre and Patrick Thee are acknowledged for generating contour lines for sites $T G$ and $S W$. We are grateful to Walter Schönenberger and Frédéric Berger for their valuable comments on a former draft and Heather Murray for improving the English of the paper. Finally, we would like to thank Swisstopo for providing the aerial photographs.

\section{References}

Agliardi, F., Crosta, G.B., 2003. High resolution three-dimensional numerical modelling of rockfalls. Int. J. Rock Mech. Mining Sci. 40, 455-471.

Bartelt, P., Stöckli, V., 2001. The influence of tree and branch fracture, overturning and debris entrainment on snow avalanche flow. Ann. Glaciol. 32, 209-216.

Baumgartner, M., 2002. Detaillierte Ersterhebungen in einem steinschlaggeschädigtem Wald im Diemtigtal. Diploma thesis. Geographisches Institut, Universität Bern, Bern.

Berger, F., Quétel, C., Dorren, L.K.A., 2002. Forest: a natural protection mean against rockfall, but with which efficiency? The objectives and methodology of the ROCKFOR project. In: Proceedings of the International Conference on Congress Interpraevent 2002 in the Pacific Rim, Matsumoto/ Japan, pp. 815-826.

Berger, F., Lievois, J., 1999. Determination of priority forest work areas and creation of green areas in risk prevention plans-an example of researcherspecialist transfer. In: Gillet, F., Zanolini, F. (Eds.). In: Proceedings of the International Conference on Mountainous Natural Hazards, Grenoble, France, pp. 412-416.

Bloetzer, W., Stoffel, M., 1998. Klimawandel als Herausforderung für die Raumplanung der Vispertäler. In: Bloetzer, W., Egli, T., Petrascheck, A., Sauter, J., Stoffel, M. (Eds.), Klimaänderungen und Naturgefahren in der Raumplanung-Methodische Ansätze und Fallbeispiele. vdf Hochschulverlag AG, Zürich, pp. 127-200.

Brang, P., Schönenberger, W., Ott, E., Gardner, R.H., 2001. Forests as protection from natural hazards. In: Evans, J. (Ed.), The Forests Handbook. Blackwell Science Ltd., Oxford, pp. 53-81.

Cattiau, V., Marie, E., Renaud, J.P., 1995. Forêt et protection contre les chutes de rochers. Ingénieries Cemagref Eau-Agrigulture-Territoire 3, 45-54.

Chauvin, C., Renaud, J.P., Rupé, C., 1994. Stabilité et gestion des forêts de protection. ONF Bull. Techn. 27, 37-52.

Dorren, L.K.A., Seijmonsbergen, A.C., 2003. Comparison of three GIS-based models for predicting rockfall runout zones at a regional scale. Geomorphology 56 (1-2), 49-64.

Dorren, L.K.A., Heuvelink, G., 2004. Effect of support size on the accuracy of a distributed rockfall model. Int. J. GIS 18, 595-609.

Dorren, L.K.A., Berger, F., 2006. Stem breakage of trees and energy dissipation at rockfall impacts. Tree Physiol. 26, 63-71.

Dorren, L.K.A., Maier, B., Putters, U.S., Seijmonsbergen, A.C., 2004 Combining field and modelling techniques to assess rockfall dynamics on a protection forest hillslope in the European Alps. Geomorphology 57 (34), 151-167.

Dorren, L.K.A., Berger, F., LeHir, C., Mermin, E., Tardif, P., 2005. Mechanisms, effects and management implications of rockfall in forests. For. Ecol. Manage. 215 (1-3), 183-195.

Dorren, L.K.A., Berger, F., Putters, U.S., in press. Real size experiments and 3D simulation of rockfall on forest slopes. Nat. Haz. Earth Syst. Sci.

Frehner, M., Wasser, B., Schwitter, R., 2005. Nachhaltigkeit und Erfolgskontrolle im Schutzwald. Wegleitung für Pflegemassnahmen in Wäldern mit Schutzfunktion. Bundesamt für Umwelt, Wald und Landschaft, Bern.

Gsteiger, P., 1993. Steinschlagschutzwald. Ein Beitrag zur Abgrenzung, Beurteilung und Bewirtschaftung. Schweiz. Z. Forstwes. 144 (2), 115-132.

Hétu, B., Gray, J.T., 2000. Effects of environmental change on scree slope development throughout the postglacial period in the Chic-Choc Mountains in the northern Gaspé Peninsula, Québec. Geomorphology 32, 335-355.

Jahn, J., 1988. Entwaldung und Steinschlag, In: Proceedings of the International Congress on Interpraevent, 1988, Graz. Band 1, pp. 185-198.
Kirkby, M.J., Statham, I., 1975. Surface stone movement and scree formation. J. Geol. 83, 349-362.

Krummenacher, B., Keusen, H.R., 1996. Rockfall simulation and hazard mapping based on digital terrain model (DTM). Eur. Geol. 12, 3335.

Kühne, R., 2005. Steinschlagsimulation in Gebirgswäldern-Validierung und Anwendung eines 3D Modells zur Quantifizierung der Schutzwirkung von Wald. Diploma thesis. Department of Geography. University of Berne, Berne.

Lafortune, M., Filion, L., Hétu, B., 1997. Dynamique d'un front forestier sur un talus d'éboulis actif en climat tempéré froid (Gaspésie, Québec). Geogr. Phys. Quat. 51 (1), 1-15.

Le Hir, C., Berger, F., Dorren, L.K.A., Quetel, C., 2004. Forest: a natural means of protection against rockfall, but how to reach sustainable mitigation? In: Proceedings of the International Symposium Interpraevent 2004, Riva/ Trient, Italy, V, pp. 59-69.

Leibundgut, H., 1986. Unsere Gebirgswälder. Paul Haupt Verlag, Bern, Stuttgart.

Mahrer, F., Bachofen, H., Brändli, U.-B., Brassel, P., Kasper, H., Lüscher, P., Riegger, W., Stierlin, H.-R., Strobel, T., Sutter, R., Wenger, C., Winzeler, K. Zingg., A., 1988. Schweizerisches Landesforstinventar: Ergebnisse der Erstaufnahme 1982-1986. Eidgenössische Forschungsanstalt für Wald, Schnee und Landschaft, Birmensdorf.

Mössmer, E.M., Ammer, U., Knoke, T., 1994. Technisch-biologische Verfahren zur Schutzwaldsanierung in den oberbayrischen Kalkalpen. Forstl. Forsch. ber. München 145: 135.

Perret, S., Baumgartner, M., Kienholz, 2004. H., Steinschlagschäden in Bergwäldern-Eine Methode zur Erhebung und Analyse. In: Proceedings of the International Symposium Interpraevent 2004, Riva/Trient, Italy, V, pp. 87 98.

Perret, S., Baumgartner, M., Kienholz, H., in press-a. Inventory and analysis of tree injuries in a rockfall-damaged forest stand. Eur. J. For. Res.

Perret, S., Stoffel, M., Kienholz, H., in press-b. Spatial and temporal rockfall activity in a forest stand in the Swiss Prealps-a dendrogeomorphological case study. Geomorphology.

Schönenberger, W., Noack, A., Thee, P., 2005. Effect of timber removal from windthrow slopes on the risk of snow avalanches and rockfall. For. Ecol. Manage. 213, 197-208.

Schneuwly, D., 2003. 500-jährige Rekonstruktion der Steinschlagfrequenz im Täschgufer anhand dendrogeomorphologischer Methoden. MSc thesis. Department of Geosciences, Geography. University of Fribourg, Fribourg.

Stoffel, M., in press. A review of studies dealing with tree rings and rockfall activity: the role of dendrogeomorphology in natural hazard research. Nat. Hazards.

Stoffel, M., 2005. Assessing the vertical distribution and visibility of rockfall scars in trees. Schweiz. Z. Forstwes. 156 (6), 195-199.

Stoffel, M., Perret, S., submitted for publication. Reconstructing past rockfall activity with tree rings: some methodological considerations. Dendrochronologia, in review.

Stoffel, M., Lièvre, I., Monbaron, M., Perret, S., 2005a. Seasonal timing of rockfall activity on a forested slope at Täschgufer (Valais, Swiss Alps) - a dendrochronological approach. Z. Geomorph. 49 (1), 89-106.

Stoffel, M., Schneuwly, D., Bollschweiler, M., Lièvre, I., Delaloye, R., Myint, M., Monbaron, M., 2005b. Analyzing rockfall activity (1600-2002) in a protection forest-a case study using dendrogeomorphology. Geomorphology 68 (3-4), 224-241.

Swisstopo, 2004. http://www.swisstopo.ch/de/vd/lwn_etat.htm (as seen on 4 March 2005).

Wasser, B., Frehner, M., 1996. Minimale Pflegemassnahmen für Wälder mit Schutzfunktionen. Wegleitung. Bundesamt für Umwelt, Wald und Landschaft (BUWAL), Berne.

Wehrli, A., Weisberg, P.J., Schönenberger, W., Brang, P., Bugmann, H., submitted for publication. Improving the establishment of a forest patch model to predict the long-term protective effect of mountain forests. Eur. J. For. Res., in review.

Zinggeler, A., Krummenacher, B., Kienholz, H., 1991. Steinschlagsimulation in Gebirgswäldern. Berichte und Forschungen des Geographischen Instituts der Universität Fribourg 3, 61-70. 